\title{
Effect of sugarcane biopolymer in vocal fold of rabbits. Comparative study with calcium hydroxyapatite ${ }^{1}$
}

\author{
Silvio José de Vasconcelos ${ }^{\mathrm{I}}$, Rodrigo Augusto Souza Leão ${ }^{\mathrm{II}}$, Sidcley Bernardino-Araújo ${ }^{\mathrm{III}}$, Mariana Montenegro de Melo Lira ${ }^{\mathrm{IV}}$, \\ Domingos Hiroshi Tsujiv \\ DOI: http://dx.doi.org/10.1590/S0102-865020150030000004 \\ IFellow PhD degree, Postgraduate Program in Otolaryngology, University of Sao Paulo (USP), Brazil. Acquisition of data, technical procedures, \\ statistical analysis, manuscript preparation. \\ IIPhD, Department of Otolaryngology and Head and Neck Surgery, Agamenon Magalhaes Hospital, Recife-PE, Brazil. Acquisition of data, technical \\ procedures. \\ IIIMaster, Department of Pathology, Federal University of Pernambuco (UFPE), Brazil. Technical procedures. \\ ${ }^{\mathrm{IV}} \mathrm{PhD}$, Associate Professor, Department of Pathology, UFPE, Recife-PE, Brazil. Macroscopic and histopathological examinations. \\ ${ }^{\vee} \mathrm{PhD}$, Associate Professor, Department of Otolaryngology, USP, Sao Paulo-SP, Brazil. Manuscript writing, critical revision.
}

\section{ABSTRACT}

PURPOSE: To compare the inflammatory reaction caused by the injection of a sugarcane biopolymer (SCB) into the vocal fold of rabbits with that caused by calcium hydroxyapatite $(\mathrm{CaH})$.

METHODS: $\mathrm{CaH}$ (Radiesse ${ }^{\circledR}$ ) and SCB gel were injected respectively into the right and left vocal cords of thirty rabbits. The rabbits were distributed into two equal groups and sacrificed at three and twelve weeks after injection. We then evaluated the intensity of the inflammatory reaction, plus levels of neovascularization, fibrogenesis and inflammatory changes in the vocal mucosa.

RESULTS: The vocal cords injected with $\mathrm{CaH}$ had a stronger inflammatory reaction by giant cells in both study periods. The SCB group had a more intense inflammatory involvement of polymorphonuclear cells three weeks after injection. SCB caused a higher level of neovascularization compared with $\mathrm{CaH}$ three weeks after the procedure.

CONCLUSION: Whereas calcium hydroxyapatite triggers a more intense and lasting inflammatory reaction mediated by giant cells, sugarcane biopolymer causes a greater response from polymorphonuclear leukocytes, as well as higher levels of vneoascularization three weeks after injection.

Key words: Vocal Cords. Dysphonia. Laryngoplasty. Biopolymers. Hydroxyapatites. Rabbits. 


\section{Introduction}

Glottal insufficiency is a common condition in otolaryngology and is also a complication associated with a number of diseases. It can impact on normal speech production by affecting subglottic pressure and the formation of the mucosal wave in the vocal folds. There may also be a deficiency in protecting the lower airway during swallowing, with a risk of aspiration and other complications such as the aspiration pneumonia ${ }^{1}$.

Medialization laryngoplasty\{Formatting Citation\} is a procedure that provides support for a vocal fold that lacks either the bulk, the mobility or both. Most commonly it involves injection of bulking material (referred to as IL hereafter) ${ }^{2}$. To this end fat can be used as a low cost autologous graft but the effects of this treatment are not long-lasting ${ }^{3}$. Once widely used, Teflon fell into disuse because of the risk of granuloma formation and increased stiffness in the injected tissue, which leads to a significant loss of vocal quality ${ }^{4,5}$.

Thesuccessfuluseofcalciumhydroxyapatitemicrospheres for the treatment of glottic insufficiency (commercially available as Radiesse ${ }^{\circledR}$ ) was initially described by Rosen and Thekdi ${ }^{6}$. Work published since then has confirmed these positive results as well as demonstrating relatively low complication $\operatorname{rates}^{7,8}$. For example, in a multi-center prospective study involving 68 patients, Rosen and colleagues ${ }^{9}$ found significant improvement in vocal and videostroboscopic parameters in patients undergoing IL with $\mathrm{CaH}$. In the treatment of glottal insufficiency due to unilateral vocal cord paralysis, a comparison of the results obtained with $\mathrm{CaH}$ IL with the results obtained by type 1 thyroplasty without rotation of the arytenoid ${ }^{10}$ found no differences in maximum phonation time and Voice Handicap Index (VHI).

However, CaH IL is not free from complications ${ }^{11}$ which can include unintended migration of the injected material, changes resulting from an intense inflammatory reaction in the injected vocal fold, as well as the formation of granulation tissue at the surgical site and irreversible damage to the mucosal wave in the vocal folds. So alternative forms of therapy need to be developed.

An extracellular heteropolysaccharide has been obtained by bacterial synthesis (Zoogloea sp) from sugar cane molasses at the experimental station of cane sugar in Carpina, Pernambuco ${ }^{12}$. Studies in experimental animals have demonstrated the mild inflammatory reaction caused by injection of this material ${ }^{13-16}$. The sugarcane biopolymer (SCB) has been studied as a substitute for dura mater in rats and used to fill the eyeballs of enucleated rabbits. In both cases the SCB was replaced by collagen fibers, which retained at least partially the mass effect of the substance on the applied $\operatorname{site}^{17,18}$. In a recent work, Leão et al. ${ }^{19}$ studied the inflammatory reaction caused by the injection of the vocal fold SCB in rabbits. The authors observed that the polymer had rheological characteristics compatible with use in long-term treatment of glottal insufficiency.

The aim of this study was to evaluate the inflammatory reaction caused by the injection of the vocal fold rabbits and compare it with the reaction caused by calcium hydroxyapatite.

\section{Methods}

The protocol was performed according to the standards of ethics of the Center for Experimental Surgery UFPE commission.

Thirty young adult male rabbits, weighing at least $2.5 \mathrm{~kg}$ and with a good nutritional status were used. The animals were kept in individual cages with free access to water and standard commercial diet.

\section{Surgical technique}

The injection of $\mathrm{SCB}$ and $\mathrm{CaH}$ was performed under general anaesthesia with the animal in the supine position. Direct laryngoscopy was performed by introducing an autostatic nasal speculum with a Ferrari brand $70 \mathrm{~mm}$ blade used for pituitary surgery. The larynx was illuminated through the speculum using the front element of a halogen light source.

The vocal folds were visualized through the nasal speculum. $0.1 \mathrm{ml} \mathrm{CaH}$ was injected into the right vocal folds using spinal needle number $25.0 .1 \mathrm{ml}$ of SCB gel (1\%) was injected into the left vocal folds. The rabbits were randomly divided into two groups. In group 1, the sacrifice of animals and sample collection were performed three weeks after injection. In group 2, the same procedure was performed 12 weeks after injection. After euthanasia, the larynx was removed and prepared for histological study.

Each larynx was sectioned in the sagittal plane into two equal halves and then each half was sectioned in the horizontal plane leaving only $3 \mathrm{~mm}$ of tissue below and above the vocal folds (Figure 1). Sections were then made using a Leika microtome and the slides were stained with hematoxylin and eosin and Masson's trichrome stain. 


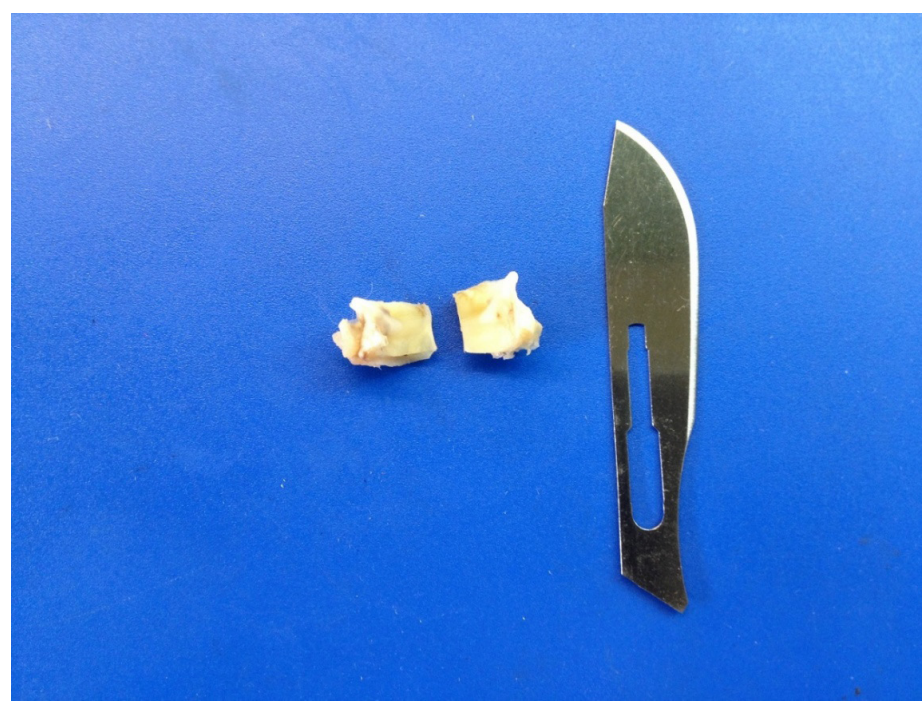

FIGURE 1 - Each hemilarynx was sectioned to contain the vocal fold and $3 \mathrm{~mm}$ of tissue above and below it.

\section{Histological study}

The intensity of the inflammatory process was assessed according to the presence and appearance of the lymphomononuclear, giant and polymorphonuclear cells. The presence and severity of fibrosis and revascularisation were also assessed. The presence of inflammatory changes in the vocal mucosa was assessed and graded according to the integrity of the epithelium, inflammatory infiltrate in the subepithelial connective tissue (mucosa) and the presence of collagen fibers in the subepithelial portion of the mucosa using the following scoring system:

1) Lymphocytic inflammatory infiltrate (LII):

Score 0: Absent

Score 1: Light: $<10 \%$ of the area occupied by inflammatory cells Score 2: Moderate: $11-50 \%$ of the area occupied by inflammatory cells

Score 3: Acute: $>50 \%$ of the area occupied by inflammatory cells 2) Giant cells (GC):

Score 0: Absent

Score 1: Light: $<10 \%$ of the area occupied by inflammatory cells Score 2: Moderate: $11-50 \%$ of the area occupied by inflammatory cells

Score 3: Acute: $>50 \%$ of the area occupied by inflammatory cells

3) Inflammatory polymorphonuclear infiltrate (IPI):

Score 0: Absent

Score 1: Lightweight: $<10 \%$ of the area occupied by inflammatory cells
Score 2: Moderate: $11-50 \%$ of the area occupied by Inflammatory Cells

Score 3: Acute: $>50 \%$ of the area occupied by inflammatory cells 4) Fibrosis:

\section{Score 0: Absent}

Score 1: Discrete: rare fibers up to $10 \%$ of the area.

Score 2: Moderate: dispersed fibers, young unmodeled between $10 \%$ and $75 \%$

Score 3: Intense: mature fibers, modeled, $75-100 \%$

\section{5) Angiogenesis}

Score 0: Absent

Score 1: Slight

Score 2: Moderate

Score 3: Intense

6) Mucosal coating

Score 0: Normal

Score 1: Aggressive inflammatory response (presence of inflammatory cells permeating the epithelium, but without continuity)

Score 2: Erosion

Score 3: Ulceration.

7) Mucosal inflammation

\section{Score 0: Absent}

Score 1: Light: $<10 \%$ of the area occupied by inflammatory cells Score 2: Moderate: $11-50 \%$ of the area occupied by Inflammatory Cells

Score 3: Acute: $>50 \%$ of the area occupied by inflammatory cells 8) Mucosal fibrosis

Score 0: Absent

Score 1: Discrete, rare fibers up to $10 \%$ of the area.

Score 2: Moderate, dispersed fibers, young unmodeled between $10 \%$ and $75 \%$

Score 3: Intense, mature fibers, modeled, $75-100 \%$

\section{Statistical analysis}

Fisher's exact test was use to assess the differences between the frequencies with which remaining traces of $\mathrm{CaH}$ and SCB were found after three to twelve weeks. The Wilcoxon test was used for analysis of data from the histological studies. Probabilities of $5 \%$ or less were $(\mathrm{p} \leq 0.05)$ regarded as significant. 


\section{Results}

Presence of material in vocal folds

Table 1 shows how often injected material remained three and 12 weeks after the procedure. There was no difference in the number of vocal folds containing $\mathrm{CaH}$ after three and 12 weeks. There was a reduction in the number of vocal folds containing SCB after 12 weeks, however, this difference was not significant $(\mathrm{p}=0.427)$.

TABLE 1 - Presence of material injected at the time of sacrifice, the group of rabbits studied three twelve weeks after injection.

\begin{tabular}{lccc}
\hline $\begin{array}{l}\text { Analysed } \\
\text { Variable }\end{array}$ & $\begin{array}{c}\text { After 3 } \\
\text { weeks }\end{array}$ & $\begin{array}{c}\text { After 12 } \\
\text { weeks }\end{array}$ & $\begin{array}{c}\text { Fisher's Exact } \\
\text { Test }\end{array}$ \\
\hline CaH & 13 & 13 & 1.0 \\
SCB & 12 & 09 & 0.427 \\
\hline
\end{tabular}

$\mathrm{HCa}=$ Calcium hydroxyapatite; $\mathrm{SCB}=$ Sugarcane biopolymer

\section{Inflammatory response}

The comparison of the histological analyses of the inflammatory response caused by the injection of $\mathrm{HCa}$ and $\mathrm{SCB}$, three and subsequently 12 weeks after injection are shown in Tables 2 and 3 respectively. Two materials did not differ in the induction of lymphocytes at three weeks $(\mathrm{p}=0.7768)$ and 12 weeks after the procedure $(\mathrm{p}=0.2402)$.

TABLE 2 - Inflammatory reaction to the injected material, three weeks after injection.

\begin{tabular}{lc|c|c|c}
\hline \multirow{2}{*}{ Analysed Variable } & & \multicolumn{2}{|c|}{ After 3 weeks } & \multirow{2}{*}{$\begin{array}{c}\text { Wilcoxon's } \\
\text { Test }\end{array}$} \\
\cline { 2 - 4 } & & $\mathbf{C a H}$ & $\mathbf{S C B}$ & \\
\cline { 2 - 4 } Lymphocytic & $\mathbf{n = 1 3}$ & $\mathbf{n = 1 2}$ & \\
\hline inflammatory infiltrate & 1 & 1 & 0 & \\
& 2 & 2 & 8 & 0.7768 \\
Giant cells & 1 & 0 & 2 & \\
& 2 & 0 & 3 & 0.0211 \\
\hline \multirow{2}{*}{ Polymorphonuclear } & 3 & 13 & 7 & \\
inflammatory infiltrate & 1 & 13 & 6 & \\
& 2 & 0 & 2 & \\
\hline
\end{tabular}

$\mathrm{CaH}=$ Calcium hydroxyapatite; $\mathrm{SCB}=$ Sugarcane biopolymer; $\mathrm{n}=$ Amount of vocal folds; 0 = Absent, $1=$ Mild, $2=$ Moderate, $3=$ Severe
TABLE 3 - Inflammatory reaction to the injected material, 12 weeks after injection.

\begin{tabular}{|c|c|c|c|c|}
\hline \multirow{3}{*}{ Analysed Variable } & & \multicolumn{2}{|c|}{ After 12 weeks } & \multirow{3}{*}{$\begin{array}{c}\text { Wilcoxon's } \\
\text { Test }\end{array}$} \\
\hline & & $\mathrm{CaH}$ & SCB & \\
\hline & & $\mathrm{n}=13$ & $\mathrm{n}=\mathbf{9}$ & \\
\hline \multirow{3}{*}{$\begin{array}{l}\text { Lymphocytic } \\
\text { inflammatory infiltrate }\end{array}$} & 0 & 1 & 0 & \multirow{3}{*}{0.2402} \\
\hline & 1 & 9 & 7 & \\
\hline & 2 & 3 & 2 & \\
\hline \multirow{3}{*}{ Giant cells } & 1 & 0 & 1 & \multirow{3}{*}{0.008} \\
\hline & 2 & 0 & 4 & \\
\hline & 3 & 13 & 4 & \\
\hline \multirow{2}{*}{$\begin{array}{l}\text { Polymorphonuclear } \\
\text { inflammatory infiltrate }\end{array}$} & 0 & 13 & 7 & \multirow{2}{*}{0.3458} \\
\hline & 1 & 0 & 2 & \\
\hline
\end{tabular}

$\mathrm{CaH}=$ Calcium hydroxyapatite; $\mathrm{SCB}=$ Sugarcane biopolymer; $\mathrm{n}=$ Amount of vocal folds; $0=$ Absent, $1=$ Mild, $2=$ Moderate, $3=$ Severe

The induction of giant cells was greater for $\mathrm{CaH}$ (Figure 2) compared to SCB. This difference could be observed after three weeks $(p=0.0211)$ and 12 weeks $(p=0.008)$. In contrast, the early induction of polymorphonuclear cells was greater for SCB ( $\mathrm{p}=0.0305)$. After 12 weeks, there was no difference in that $(p=0.3458)$ parameter. In both situations, the inflammatory reaction was marked mainly by the presence of eosinophils, and neutrophils were rare (Figure 3 ).

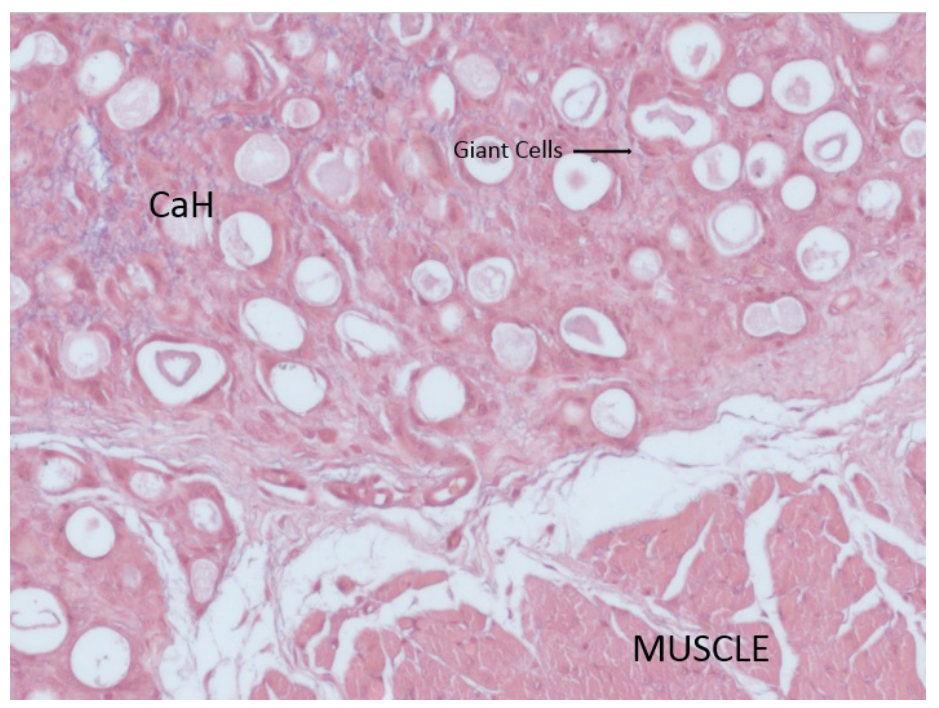

FIGURE 2 - Transverse histological section of the vocal fold injected $\mathrm{CaH}$ after three weeks of the procedure. Observe multinucleated giant cells (arrow) involving the injected material (magnification x400). 


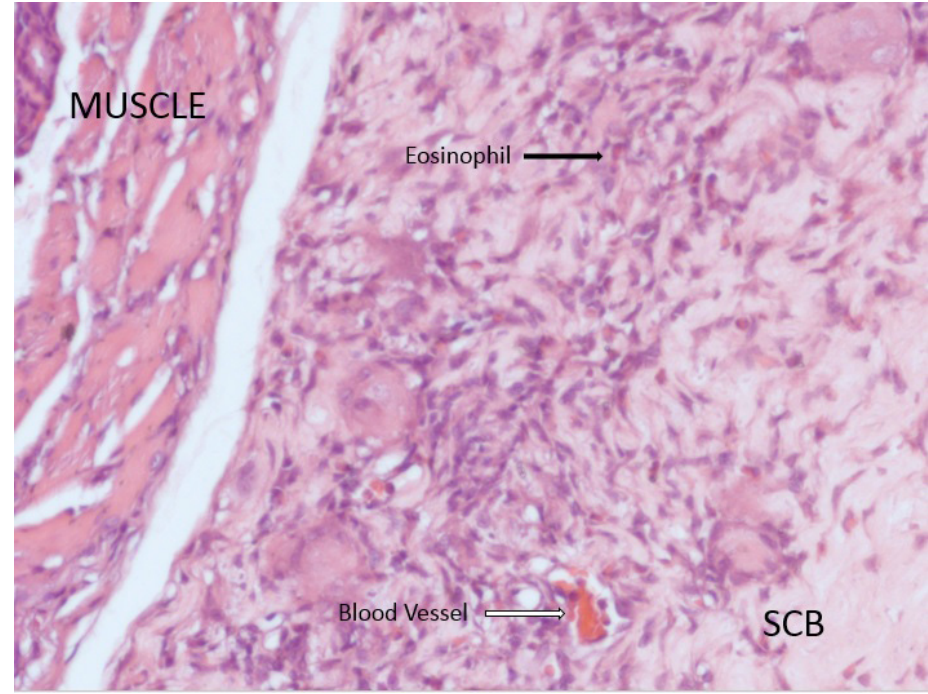

FIGURE 3 - Transverse histological section of the vocal fold injected SCB, three weeks after the procedure. Observe the predominant inflammatory cells infiltrated by polymorphonuclear type, especially eosinophils (black arrow). It is also noticed the presence of neovascularization within the injected material (white arrow) (magnification x400).

\section{Fibrosis and angiogenesis}

Fibrosis occurring in the injection site was evaluated for both substances (Tables 4 and 5). After three weeks, no difference was found, but after 12 weeks, SCB showed mild increase in fibrosis (Figure 4). However, the difference between the two substances was not statistically significant $(\mathrm{p}=0.7897)$.

TABLE 4 - Presence of fibrosis and angiogenesis three weeks after application of $\mathrm{CaH}$ and SCB.

\begin{tabular}{lc|c|c|c}
\hline \multirow{2}{*}{ Analysed Variable } & \multicolumn{2}{|c|}{ After 3 weeks } & \multirow{2}{*}{$\begin{array}{c}\text { Wilcoxon's } \\
\text { Test }\end{array}$} \\
\cline { 2 - 4 } & $\mathbf{C a H}$ & $\mathbf{S C B}$ & $\mathbf{n}=\mathbf{1 2}$ & \\
\cline { 2 - 4 } Fibrosis & $\mathbf{n = 1 3}$ & 8 & 1.0 \\
\hline \multirow{2}{*}{ Angiogenesis } & 0 & 9 & 4 & \\
& 1 & 4 & 2 & \\
& 0 & 10 & 8 & 0.0083 \\
\hline
\end{tabular}

$\mathrm{CaH}=$ Calcium hydroxyapatite $\mathrm{SCB}=$ Sugarcane biopolymer; $\mathrm{n}=$ Amount of vocal folds; $0=$ Absent, $1=$ Mild, $2=$ Moderate

TABLE 5 - Presence of fibrosis and angiogenesis 12 weeks after application of $\mathrm{CaH}$ and SCB.

\begin{tabular}{|c|c|c|c|c|}
\hline \multirow{3}{*}{\multicolumn{2}{|c|}{ Analysed Variable }} & \multicolumn{2}{|c|}{ After 12 weeks } & \multirow{3}{*}{$\begin{array}{c}\text { Wilcoxon's } \\
\text { Test }\end{array}$} \\
\hline & & \multirow{2}{*}{$\begin{array}{c}\mathrm{CaH} \\
\mathrm{n}=13\end{array}$} & \multirow{2}{*}{$\begin{array}{c}\text { BPCA } \\
n=9\end{array}$} & \\
\hline & & & & \\
\hline \multirow{2}{*}{ Fibrosis } & 0 & 9 & 4 & \multirow{2}{*}{0.7897} \\
\hline & 1 & 4 & 5 & \\
\hline \multirow{3}{*}{ Angiogenesis } & 0 & 9 & 1 & \multirow{3}{*}{0.1236} \\
\hline & 1 & 4 & 6 & \\
\hline & 2 & 0 & 2 & \\
\hline
\end{tabular}

$\mathrm{CaH}=$ Calcium hydroxyapatite; $\mathrm{SCB}=$ Sugarcane biopolymer; $\mathrm{n}=$ Amount of vocal folds; $0=$ Absent, 1 = Mild, $2=$ Moderate

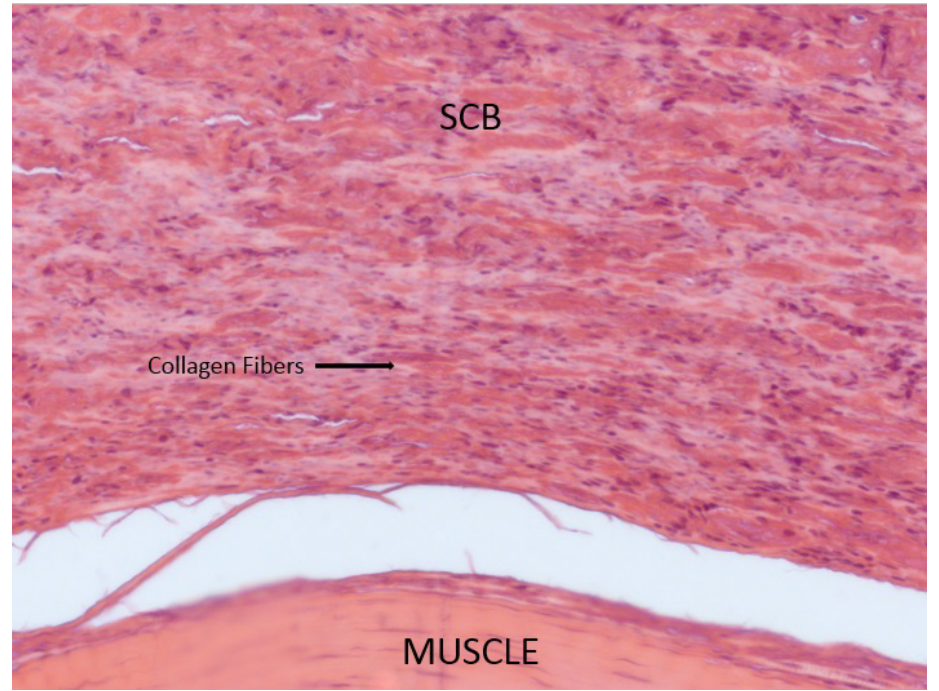

FIGURE 4 - Transverse histological section of the vocal fold injected SCB, after 12 weeks of the procedure. Note the presence of fibrosis at the injection site in the form of collagen fibers (arrow) (magnification $\mathrm{x} 400$ ).

Three weeks after the injection, SCB had triggered a significant increase in the formation of blood vessels at the injection site (Figure 4) $(\mathrm{p}=0.0083)$. Increased angiogenesis was also observed after 12 weeks (Table 5), but the value was not statistically significant $(\mathrm{p}=0.1236)$.

\section{Changes in vocal mucosa}

The inflammatory reaction triggered by injecting $\mathrm{HCa}$ and SCB was assessed after three weeks (Table 6) and 12 weeks (Table 7). At three weeks no change in the integrity of the mucosa was observed in the vocal folds that had received SCB (Figure 5). In the case of $\mathrm{CaH}$ there was one case of mild inflammatory infiltrate in the epithelium during that period. This difference was not statistically significant $(\mathrm{p}=0.3478)$. No significant differences were observed after 12 weeks.

TABLE 6 - Changes in vocal mucosa three weeks after application of $\mathrm{CaH}$ and SCB.

\begin{tabular}{|c|c|c|c|c|}
\hline \multirow{3}{*}{ Analysed Variable } & & \multicolumn{2}{|c|}{ After 3 weeks } & \multirow{3}{*}{$\begin{array}{l}\text { Wilcoxon's } \\
\text { Test }\end{array}$} \\
\hline & & $\mathrm{CaH}$ & SCB & \\
\hline & & $n=13$ & $n=12$ & \\
\hline \multirow{2}{*}{ Mucosal coating } & 0 & 12 & 12 & \multirow{2}{*}{0.3478} \\
\hline & 1 & 1 & 0 & \\
\hline \multirow{2}{*}{ Mucosal inflammation } & 0 & 5 & 4 & \multirow{2}{*}{1.0} \\
\hline & 1 & 8 & 8 & \\
\hline \multirow{2}{*}{ Mucosal fibrosis } & 0 & 12 & 10 & \multirow{2}{*}{0.7728} \\
\hline & 1 & 1 & 2 & \\
\hline
\end{tabular}

$\mathrm{CaH}=$ Calcium hydroxyapatite; $\mathrm{SCB}=$ Sugarcane biopolymer; $\mathrm{n}=$ Amount of vocal folds; $0=$ Absent, $1=$ Mild 
TABLE 7 - Changes in vocal mucosa 12 weeks after application of $\mathrm{CaH}$ and $\mathrm{SCB}$.

\begin{tabular}{|c|c|c|c|c|}
\hline \multirow{3}{*}{ Analysed Variable } & & \multicolumn{2}{|c|}{ After 12 weeks } & \multirow{3}{*}{$\begin{array}{c}\text { Wilcoxon's } \\
\text { Test }\end{array}$} \\
\hline & & $\mathrm{CaH}$ & BPCA & \\
\hline & & $n=13$ & $\mathbf{n}=\mathbf{9}$ & \\
\hline \multirow{2}{*}{ Mucosal coating } & 0 & 13 & 9 & \\
\hline & 1 & 0 & 0 & \\
\hline \multirow{2}{*}{ Mucosal inflammation } & 0 & 10 & 6 & \multirow{2}{*}{0.1489} \\
\hline & 1 & 3 & 3 & \\
\hline \multirow{2}{*}{ Mucosal fibrosis } & 0 & 11 & 8 & \multirow{2}{*}{0.7656} \\
\hline & 1 & 2 & 1 & \\
\hline
\end{tabular}

$\mathrm{CaH}=$ Calcium hydroxyapatite; $\mathrm{SCB}=$ Sugarcane biopolymer; $\mathrm{n}=$ Amount of vocal folds; $0=$ Absent, $1=$ Mild

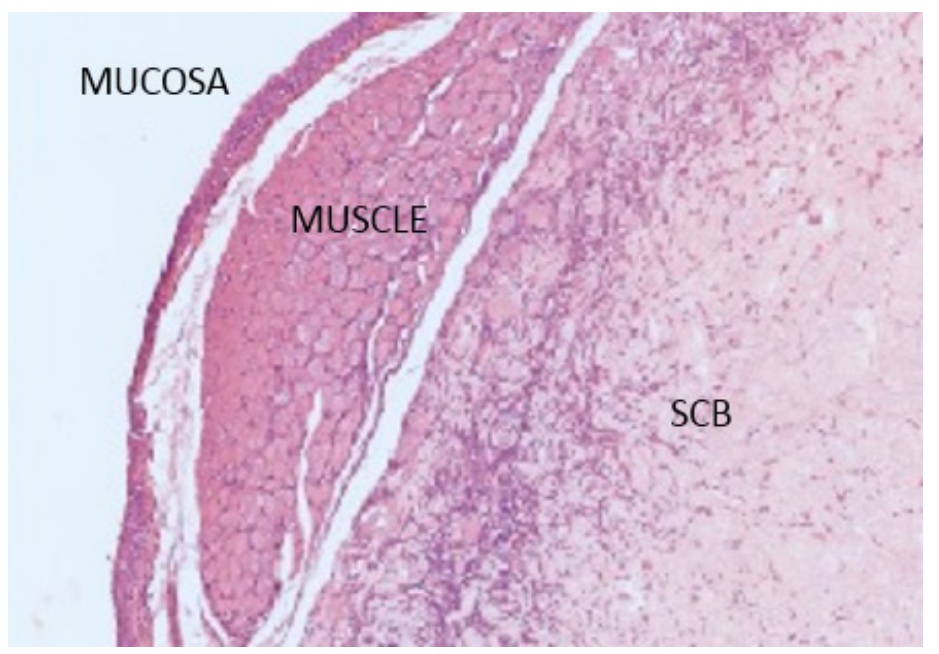

FIGURE 5 - Histological section of the vocal folds injected with SCB, three weeks after the procedure. There is a panoramic view of the vocal fold, with intact mucosa without inflammatory infiltrate or subepithelial fibrosis (magnification x100).

When we investigated the inflammatory infiltrate in the subepithelial connective tissue, we observed that there was no significant difference between $\mathrm{CaH}$ and $\mathrm{SCB}$ at three and 12 weeks after the injection. Regarding the presence of fibrosis in the subepithelial region of the mucosa, the analysis performed three weeks after the injection showed no to mild fibrosis in the region (Table 6 and Figure 6) for both materials. Twelve weeks after injection there was only mild subepithelial fibrosis in a few histological sections for both materials with absence of fibrosis the most common finding (Table 7).

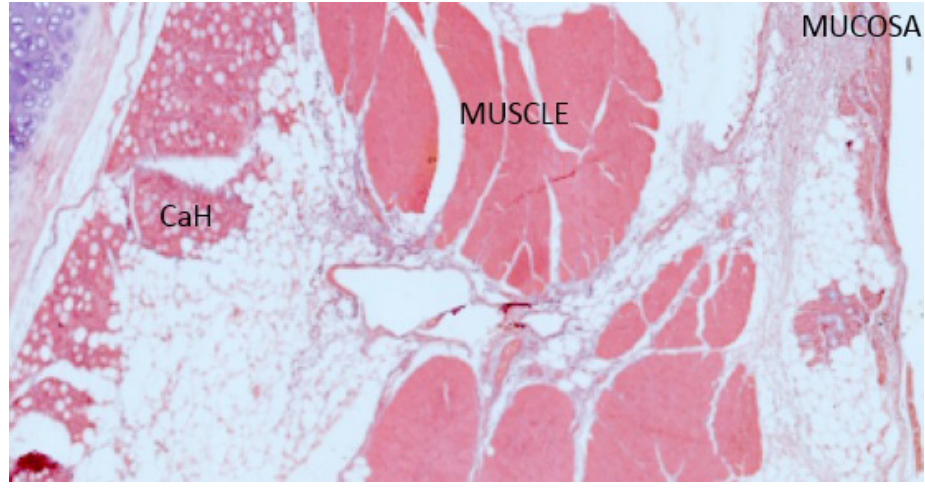

FIGURE 6 - Histological section of the vocal folds injected with $\mathrm{HCa}$ 12 weeks after the procedure. There is a panoramic view of the vocal fold, with intact mucosa without significant inflammatory infiltrate or subepithelial fibrosis (magnification $\mathrm{x} 40$ ).

\section{Discussion}

A variety of synthetic carbohydrate-based polymers have been studied for use in biomedicine over the past decades ${ }^{20}$. Amongst these materials is $\mathrm{SCB}$, which was developed at the Federal University of Pernambuco in 2000 by a process involving bacterial synthesis from molasses of sugar cane ${ }^{12}$. Since its development, SCB has been studied as a material for implantation in various areas of medicine, with promising results due to its low toxicity and good integration with host tissue $e^{13-16}$.

Further studies have shown that there is a discrete biopolymer-triggered inflammatory reaction at the implanted site and, in addition, that the material is gradually resorbed by the body. In studies evaluating SCB's use as a substitute for dura mater in rats and filling eviscerated eye-sockets in rabbits substitution of the polymer by organic material has also been observed. In both cases collagen deposition maintained the integrity of the dura mater and volume of the eye $\mathrm{e}^{17,18}$. This finding suggests that the mass effect achieved by the injection of SCB may persist after the resorption of the polymer.

When evaluating the inflammatory response triggered by each substance, we can see similarities between them, as well as differences. As pointed out by Rosen et al. ${ }^{9}$, one of the characteristics of a good material for vocal cord augmentation is that it is biologically inert. This suggests that the best material will trigger the lowest inflammatory response. We conclude, with respect to the parameters measured, that in the vocal folds of rabbits the two substances tested are equivalent. Histological analysis of the specimens showed that $\mathrm{HCa}$ triggered an inflammatory response that was more long-lasting than SCB. 
The finding of a significant inflammatory reaction based on giant cells may explain, at least in part, the inflammatory complications described in the literature arising from the use of Tefon ${ }^{\circledR}$ and $\mathrm{CaH}$ in humans, such as foreign body reactions and the formation of granulomas ${ }^{4,11}$.

The inflammatory reaction to SCB mediated by polymorphonuclear cells was greater for the polymer than for $\mathrm{HCa}$ at three weeks after the injection. This finding suggests that the inflammatory response based on this cell type decreases with time and after 12 weeks of injection the two substances are equivalent with respect to this variable.

Another feature of the response to SCB relates to the formation of new blood vessels at the site of implantation. This was pronounced after three and 12 weeks of injection. However, this difference was only statistically significant after three weeks. The presence of neovascularization is important for the organization of the extracellular matrix and collagen deposition at the injury site ${ }^{21}$. If replacing the polymer collagen fibers is desirable to keep the mass effect achieved by the injection of the material, this histological finding could be indicative of a good functional outcome.

It should be noted that the study was done with a single concentration (1\%) of SCB hydrogel. Different concentrations may produce different results, say, by affecting the duration of medialization. Something similar has already been described for hyaluronic acid ${ }^{22}$. Moreover, the study did not evaluate the mean time to absorption of the material and the evaluation of the inflammatory response to the materials was only followed until the twelfth week.

\section{Conclusions}

Injected into the vocal folds of rabbits, sugarcane biopolymer showed a comparable inflammatory reaction to calcium hydroxyapatite in most parameters studied. Whereas $\mathrm{CaH}$ triggered a more intense and lasting inflammatory reaction mediated by giant cells, SCB caused a greater response from polymorphonuclear leukocytes, as well as a higher degree of revascularisation three weeks after the injection.

\section{References}

1. Giraldez-Rodriguez LA, Johns M. Glottal insufficiency with aspiration risk in dysphagia. Otolaryngol Clin North Am. 2013;46(6):1113-21. doi: 10.1016/j.otc.2013.09.004.

2. Rosen C, Mallur P. Office-Based Laryngeal Injections. Otolaryngol Clin North Am. 2013;46:85-100. doi: 10.1016/j.otc.2012.08.020.

3. Carneiro CDG, Hiroshi D, Sennes LU, Ximenes JA. Uso da gordura e fáscia muscular autólogas no tratamento da insuficiência glótica.
Rev Bras Otorrinolaringol. 2006;72(1):140-4. PMID: 16917566.

4. Tate JR, Belafsky PC, Vandewalker K. Teflon granuloma. Ear Nose Throat J. 2007;86(3):134-6. PMID: 17427770.

5. Rivera-Serrano CM, Smith LJ. Laryngeal teflon granuloma: endoscopy, laryngeal videostroboscopy, and CT imaging. Ear Nose Throat J. 2011;90(3):E25-6. PMID: 21412729.

6. Rosen CA, Thekdi AA. Vocal fold augmentation with injectable calcium hydroxylapatite: short-term results. J Voice. 2004;18(3):38791. doi: 10.1016/j.jvoice.2004.02.001.

7. Woo S, Son Y, Lee S, Park J. The efficiency of the injection laryngoplasty technique using calcium hydroxyapatite (CaHA): the thyrohyoid approach versus the cricothyroid approach. J Voice. 2012;27:236-41. doi: 10.1016/j.jvoice.2012.11.001.

8. Belafsky PC, Postma GN. Vocal fold augmentation with calcium hydroxylapatite. Otolaryngol Head Neck Surg. 2004;131(4):351-4. doi: 10.1016/j.otohns.2004.03.025.

9. Rosen CA, Gartner-Schmidt J, Casiano R, Anderson TD, Johnson F, Reussner L, Remacle M, Sataloff RT, Abitbol J, Shaw G, Archer S, McWhorter A. Vocal fold augmentation with calcium hydroxylapatite (CaHA). Otolaryngol Head Neck Surg. 2007;136(2):198-204. doi: 10.1016/j.otohns.2006.07.014.

10. Shen T, Damrose EJ, Morzaria S. A meta-analysis of voice outcome comparing calcium hydroxylapatite injection laryngoplasty to silicone thyroplasty. Otolaryngol Head Neck Surg. 2013;148(2):197_ 208. doi: $10.1177 / 0194599812464193$.

11. DeFatta RA, Chowdhury FR, Sataloff RT. Complications of injection laryngoplasty using calcium hydroxylapatite. J Voice. 2012;26(5):614-8. doi: 10.1016/j.jvoice.2011.08.005.

12. Paterson-Beedle M, Kennedy J, Melo FA, Lloyd L, Medeiros V. A cellulosic exopolysaccharide produced from sugarcane molasses by a Zoogloea sp. Carbohydr Polym. 2000;42(4):375-83. doi: 10.1016/ S0144-8617(99)00179-4.

13. Barros D. Miringoplastia com enxerto livre de membrana de biopolímero de cana de açúcar e fáscia autóloga em Chinchilla laniger. An Fac Med Univ Fed Pernambuco. 2006;51(1):45-51. doi: 10.1590/S1808-86942011000100008.

14. Coelho M, Carrazoni P, Monteiro V, Melo F, Mota R, Filho F. Biopolímero Produzido a partir da cana-de-açucar para cicatrização cutânea. Acta Cir Bras. 2002;17(Suppl 1). doi: 10.1590/S010286502002000700002 .

15. Lima F, Hirakawa P. Resposta inflamatória a membranas de biopolímero de cana-de-açúcar e telas de polipropileno ${ }^{\circledR}$ implantadas no peritôneo parietal de ratos. An Fac Med Univ Fed Pernambuco. 2005;50(1):37-40. PMID: 21952662.

16. Lucena G. Utilização do biopolímero de cana-de-açúcar como novo material para sling pubo vaginal : análise estereológica (Doutorado). Universidade Federal de Pernambuco, Departamento de Cirurgia, 2007.

17. Cordeiro-Barbosa FDA, Aguiar JLDA, Lira MMDM, de Pontes Filho NT, Bernardino-Araújo S. Use of a gel biopolymer for the treatment of eviscerated eyes: experimental model in rabbits. Arq Bras Oftalmol. 2012;75(4):267-72. PMID: 23258659.

18. Lima F. Membrana de biopolímero de cana-de-açúcar como substituto de dura-máter em ratos Wistar (Doutorado). Universidade Federal de Pernambuco, Departamento de Cirurgia, 2008.

19. Leão RA, Assis RC, Caldas Neto SS, Vasconcelos SJ. Otorhinolaryngology Effect of sugarcane biopolymer gel injected in rabbit vocal fold. Braz J Otorhinolaryngol. 2014;80(3):220-5. PMID: 25153106.

20. Varma A, Kennedy J, Galgali P. Synthetic polymers functionalized by carbohydrates: a review. Carbohydr Polym. 2004;56(4):429-45. doi: 10.1016/j.carbpol.2004.03.007.

21. Tonnesen MG, Feng X, Clark RAF. Angiogenesis in wound healing. J Invest Dermatol. 2000;5:40-6. PMID: 11147674. 
22. Lau DP, Lee GA, Wong SM, Lim VP, Chan YH, Tan NG, Rammage LA, Morrison MD. Injection laryngoplasty with hyaluronic acid for unilateral vocal cord paralysis. Randomized controlled trial comparing two different particle sizes. J Voice. 2010;24(1):113-8. doi: 10.1016/j.jvoice.2008.05.007.

\section{Correspondence:}

Dr. Domingos Hiroshi Tsuji

Rua Peixoto Gomide, 515/Cj 145

01409-001 São Paulo - SP Brasil

Tel.: (55 11)3251-5504

domingostsuji@terra.com.br

Received: Nov 19, 2014

Review: Jan 20, 2015

Accepted: Feb 18, 2015

Conflict of interest: none

Financial source: none

${ }^{1}$ This was a joint effort between Federal University of Pernambuco (UFPE) and University of Sao Paulo (USP). The experimental part of the study was performed at the Department of Experimental Surgery, UFPE. Histological analysis of the specimens was performed at the Department of Pathology, UFPE, Recife-PE, Brazil. Part of PhD degree thesis, Postgraduate Program in Otolaryngology, USP. Tutor: Dr. Domingos Hiroshi Tsuji. 